\title{
Economics of broom snakeweed control on the Southern Plains
}

\author{
BRENT D. CARPENTER, DON E. ETHRIDGE, AND RONALD E. SOSEBEE
}

\begin{abstract}
Revenues associated with controlling broom snakeweed (Xanthocephalum sarothrae) on 6 soils with heavy, moderate, and light infestations of snakeweed were estimated. The analysis considered economic returns associated with grass yield response and those from livestock efficiency gains. Results indicate that control of moderate and heavy infestations is generally economically feasible, but treatment of light infestations does not pay. The economic benefits from livestock efficiency gains are generally greater than the value of increased grass production.
\end{abstract}

Key Words: brush control, broom snakeweed, Xanthrocephalum sarothrae

Broom snakeweed [ Xanthocephalum sarathrae (Pursh) Shinners] is an aggressive invader of rangelands in the western United States and northern Mexico. Broom snakeweed reduces productivity and causes economic losses by poisoning livestock and severely reducing yield of desirable forage. Ranchers on the southern High Plains and Canadian-Pecos valley of west Texas and New Mexico are faced with the heaviest infestations and the most severe management problems (McDaniel and Sosebee 1987).

As a perennial evergreen, with adequate winter moisture snakeweed has a competitive advantage over associated forage due to early season growth and an extensive shallow root system, which enables the plant to deplete soil moisture and nutrients before native grasses begin seasonal growth. As snakeweed densities increase and carrying capacity is reduced, economic losses to ranchers intensify. For shortgrass and desert grass regions of the Southwest, heavy infestations can suppress forage yields to less than $10 \%$ of the production on snakeweed-free range (Sosebee 1985).

When poisoning occurs, cow herd performance is impaired through abortions or death of mature cows. Conception rates decrease and calves which are born have considerably lower weaning weights. Persistent retained placentas and reproductive disorders often occur independently or in combination with other reactions to toxicity (Dollahite and Anthony 1956, 1957; Dollahite and Allen 1959).

Improvements in herbicide efficacy and treatment recommendations have made it possible to effectively control broom snakeweed infestations. Sosebee et al. (1979) significantly reduced snakeweed over a 3-year period with $.6 \mathrm{~kg}$ a.i./ ha of tebuthiuron. McDaniel and Duncan (1987) achieved $100 \%$ mortality with fall treatments of picloram as low as $.14 \mathrm{~kg} / \mathrm{ha}$ and metsulfuron as low as $.034 \mathrm{~kg} / \mathrm{ha}$. Experimental evidence has also shown that removing snakeweed can increase forage production of desirable species by 100 to $800 \%$ in the first growing season (Gesink et al. 1973, Ueckert 1979, McDaniel et al. 1982). Yet it is not completely understood how biological and economic factors interact over time to affect the economic outcome of a treatment. Only gross estimates of produc-

\footnotetext{
Authors are county extension agent, Texas Agricultural Extension Service, and professors, Departments of Agricultural Economics and Range and Wildlife Managernent, Texas Tech University, respectively. The authors thank Kenneth Bowman, David Wester, and Bill Dahl for their suggestions on the manuscript. Texas Tech University College of Agricultural Sciences Publication T-1-308.

Manuscript accepted 30 June 1990.
}

tion levels before and after control have been available (Torell et al. 1987).

The economic success of a herbicide application depends on the magnitude of both the forage and livestock responses and their patterns over a period of time. Treatment life, or the duration of additional production after treatment, is also a determinant of investment profitability. For the cow-calf manager there is an element of uncertainty associated with these temporal variables.

The purpose of this study was to determine the economic feasibility of investing in herbicidal control of broom snakeweed, based on the benefits contributed to a cow-calf operation. Specific objectives were to quantify the biological responses of grass and cattle through time and to determine the economic value of the additional production over the estimated treatment life.

\section{Methods and Procedures}

The procedures used to achieve the study objectives can be summarized in 3 general steps. First, the biological response of snakeweed and the corresponding forage response was estimated by multiple regression techniques to produce a model of herbage production over the life of the treatment. A similar approach has been used to estimate response functions through time for other types of range improvement practices (Ethridge et al. 1984, 1985, 1987). Second, estimates for cow-calf efficiency gains were developed for various levels of snakeweed infestation. This was accomplished through a survey of selected professional range specialists and is explained in Carpenter et al. (1991). Finally, the total economic benefits of snakeweed control were calculated by combining the value of the additional beef output generated solely from an increase in carrying capacity with the value of the additional beef output derived from the suppression of poisoning effects. This was achieved by developing budgets based on the initial and posttreatment quantities of forage production per land unit and beef output for a cow-calf production unit. Net present value was used as the criteria for determining economic feasibility.

Data for estimating the snakeweed and grass production response functions were adapted from treatments of snakeweed infestations using a number of herbicides, treatment rates, and dates of application on 6 soil types. Data were aggregated from time-series and cross-sectional trials conducted by researchers at Texas Tech University over a 9-year period, 1979-1987, in 6 small plot experiments on 2 sites in eastern New Mexico and in a single on-going experiment on 7 commercially treated sites in west Texas and eastern New Mexico (Alliney 1982, Courtney 1984, R.E. Sosebee unpublished data). The number of replications varied from 3 to 10 for the different experiments. Each observation of the data in the statistical analysis was the mean value of the replications. Data used to estimate snakeweed response consisted of 117 observations of only picloram treatment during the fall months. Data used to estimate grass response consisted of 144 observations from treatments at various times of the year.

In addition to herbage yield data, precipitation values from the nearest weather station (U.S. Dept. of Commerce 1979-1987) were used as a proxy for rainfall at the treated site. Rainfall corresponding with the snakeweed life cycle was divided into two 6-month 
periods to represent summer rain (April-October) and winter rain (September-March).

Prior to empirical estimation of the analytical model, structural relationships were established for grass yield on snakeweedinfested rangeland. The explanatory variables identified for grass production were precipitation, soil type as an indicator of potential productivity of the soil, and the quantity of snakeweed present. However, since snakeweed quantity is also affected by precipitation and soil type, these variables have an indirect effect on grass production. The direction of influence is one-way since broom snakeweed competes with grass during the summer growing season, but grass yield does not appear to suppress the production of snakeweed after the first 2-3 years of snakeweed infestation. The most appropriate model of these relationships is a two-equation model where a set of variables is used to explain snakeweed production, which in turn affects the quantity of grass.

The above theoretical relationships are expressed as:

$A X S_{t}=a_{0}+a_{1} T R+a_{2} W R+a_{3} W R * F M+a_{4} S R+a_{5} S R * F M+a_{6} S T_{i}+a_{7} F M+a_{8} t^{2}+\epsilon$ $G_{t}=b_{0}+b_{1} X S_{t}+b_{2} S R * S T_{i}+b_{3} W R * S T_{i}+b_{4} S T_{i}+e$

where $\mathrm{AXS}_{\mathbf{t}}=$ additional annual snakeweed production in year $t$ (treated production minus untreated production), $\mathrm{kg} /$ ha.

$\mathbf{G R}_{\mathbf{t}}=$ annual grass production in year $\mathrm{t}, \mathrm{kg} / \mathrm{ha}$.

$\mathrm{XS}_{\mathrm{t}}=$ annual snakeweed production in year $\mathrm{t}, \mathrm{kg} / \mathrm{ha}$.

$\mathrm{TR}=$ picloram treatment rate, $\mathrm{kg} \mathrm{ai} / \mathrm{ha}$.

$F M=$ formulation of herbicide; 1 if pellet, 0 if liquid.

$\mathrm{SR}=$ summer rainfall (April-September), $\mathrm{cm}$.

$\mathrm{WR}=$ winter rainfall (October-March), $\mathrm{cm}$.

$\mathrm{ST}_{\mathrm{i}}=$ soil type, identified as a set if binary indicator variables; $\mathbf{S T}_{1}=1$ if Potter loam soil, $\mathbf{S T}_{2}=1$ if Miles sandy loam, $\mathrm{ST}_{3}=1$ if Vernon clay loam, $\mathrm{ST}_{4}=1$ if Tina fine sandy loam, $\mathrm{ST}_{5}=1$ if Arvana fine sandy loam, Kimbrough-Lea gravelly loam if all are 0 .

$\mathrm{t}=$ time after treatment, years.

$\mathbf{e , \epsilon}=$ stochastic error terms.

$\mathbf{a}, \mathbf{b},=$ parameters.

ASX $_{\mathrm{t}}$ is a measure of the snakeweed quantity after treatment and depends on the initial quantity. It measures the amount of snakeweed killed and is negative as long as the treatment has the anticipated effect. The absolute value of $\mathrm{AXS}_{\mathfrak{t}}$ becomes smaller as snakeweed reinvades the site and approaches the pre-treatment quantity.

The analysis was facilitated by limiting the continuum of pretreatment snakeweed levels to light, moderate, and heavy categories. Quantities of snakeweed production with a heavy infestation were determined from the untreated plots in the data set. Snakeweed quantities for the various soil types were not identical since herbage production is a function of soil type or potential productivity of the soil. A moderate infestation was then defined as $50 \%$ of heavy and light infestation as $20 \%$ of heavy. Upon estimation of the response functions, corresponding quantities for grass production were also estimated. These pre-treatment snakeweed and grass yields formed the biological basis for determining the annual changes in herbage output and ultimately the economic benefit of changes over time in carrying capacities and cow-herd performance rates. These categories provide the basis for calculating additional net revenue associated with the snakeweed reduction.

For purposes of this analysis, the 2 variables of primary interest in the estimated analytical model were time $(t)$ and the relationship of snakeweed $\left(X S_{t}\right)$ to grass $\left(G R_{t}\right)$. The empirical response functions were simplified to single variable equations for each of the significantly different soil types by specifying soil types, treatment at the recommended rates of liquid picloram $(.28 \mathrm{~kg} / \mathrm{ha})$ and normal precipitation $(S R=11.4 \mathrm{~cm}, W R=33 \mathrm{~cm}$ ), resulting in AXS as a function of $t$, and $G_{t}$ as a function of $X S_{t}$. These equations were then used to calculate the annual herbage quantities over the life of the treatment, which was terminated in the year that $\mathrm{AXS}_{\mathrm{t}}$ became positive.

Snakeweed production for a given year $\left(\mathrm{XS}_{\mathrm{t}}\right)$ was determined by allowing $t$ to vary in the $\mathrm{AXS}_{\mathrm{t}}$ function and calculating the difference in $\mathrm{AXS}_{\mathrm{t}}$ and $\mathrm{XS}_{0}$, where $\mathrm{XS}_{0}$ is the pre-treatment level of snakeweed for the given soil. $\mathrm{GR}_{t}$ was then solved for by specifying the predicted values of $X S_{t}$ in the $G_{t}$ function. Given the pretreatment and annual quantities for snakeweed and grass production, the remaining biological information relevant to the economic analysis was calculation of cow-herd peformance and carrying capacity over the treatment life.

Table 1. Livestock production parameters for a typical cow-calf operation on the southern plains.

\begin{tabular}{lrrrr}
\hline \hline & \multicolumn{4}{c}{ Level of snakeweed infestation } \\
\cline { 2 - 5 } Production description & None & Light & Moderate & Heavy \\
\hline Cow replacement rate (\%) & 12 & 12 & 12 & 12 \\
Bull to cow ratio (\%) & 5 & 5 & 5 & 5 \\
Calf crop at birth (\%) & 85 & 85 & 71.7 & 59.1 \\
Calf death rate (\%) & 1 & 1 & 1 & 1 \\
Cow death rate (\%) & 1 & 1 & 1 & 4.7 \\
Steer calf weaning wt. (kg) & 204 & 204 & 181 & 162 \\
Heifer calf weaning wt. (kg) & 193 & 193 & 171 & 153 \\
\hline
\end{tabular}

Cow-herd performance was determined on the basis of a cow producing unit (CPU), where a CPU is composed of the total animal inputs involved in producing a weaned calf. Snakeweed poisoning reduces cow herd output by negatively impacting the calf crop, weaning weights, and the number of cows (Carpenter et al. 1991). The magnitude of the poisoning impact on cow-herd performance depends on the quantity of snakeweed present. Estimates for beef production losses were obtained in the survey for each category of infestation (Table 1). The toxicity effects associated with various post-treatment quantities of snakeweed were determined by extrapolating between the estimated production parameters with light, moderate, and heavy infestations. The extrapolated relationships for abortions and reduction in weaning weight increased at a decreasing rate, while the cow death rate and the reduction of conception rates increased linearly. Given the quantity of snakeweed in any year after treatment, the expected performance of the cow herd was then obtained for each soil type. The estimated production under snakeweed conditions was compared with production for a typical snakeweed free cow-calf operation in the Southern Plains region to arrive at estimates for additional beef production per CPU for each year of the treatment life.

Grass production in each year was converted to carrying capacity based on the requirement that approximately 9,072 total $\mathrm{kg}$ of grass is necessary to support a CPU for 12 months (Sosebee et al. 1981). One-half of the total grass production is available for consumption and disappearance and one-half is left for plant growth and reproduction. Therefore, carrying capacity in CPUs per ha =

Table 2. Beef cattle prices.

\begin{tabular}{lccc}
\hline & \multicolumn{3}{c}{ Price $(\$ /$ cwt.) } \\
\cline { 2 - 4 } Cattle class & Low & Mean & High \\
\hline Steers & 66.80 & 77.76 & 88.72 \\
Heifers & 56.04 & 66.34 & 75.64 \\
Cull cows & 37.60 & 41.98 & 46.40 \\
\hline
\end{tabular}


Table 3. Pre-treatment quantities of snakeweed (XS) and predicted grass (GR) production, by soil type.

\begin{tabular}{|c|c|c|c|c|c|c|c|c|}
\hline \multirow{3}{*}{$\begin{array}{l}\text { Level of } \\
\text { infestation }\end{array}$} & \multicolumn{8}{|c|}{ Soil type } \\
\hline & \multicolumn{2}{|c|}{ Arvana } & \multicolumn{2}{|c|}{ Vernon } & \multicolumn{2}{|c|}{ Tina } & \multicolumn{2}{|c|}{ Miles } \\
\hline & XS & $\overline{\mathrm{GR}}$ & $\mathbf{X S}$ & $\overline{\mathrm{GR}}$ & XS & $\overline{\text { GR }}$ & $\mathbf{X S}$ & $\overline{\mathbf{G R}}$ \\
\hline & \multicolumn{8}{|c|}{. Herbage Production (kg/ha) $\ldots \ldots$} \\
\hline None & 0 & 1252 & 0 & 1390 & 0 & 1499 & 0 & 2211 \\
\hline Light & 358 & 1139 & 381 & 1269 & 403 & 1371 & 672 & $\begin{array}{l}2211 \\
1998\end{array}$ \\
\hline Moderate & 896 & 969 & 952 & 1089 & 1008 & 1179 & 1680 & 1680 \\
\hline Heavy & 1792 & 687 & 1904 & 788 & 2016 & 861 & 3360 & 1149 \\
\hline
\end{tabular}

$\left(G_{t} / 9,072\right)$ where $G R_{t}$ is the annual grass yield.

In the economic analysis, the value of the additional beef production from the 2 treatment effects is the sum of the discounted annual net revenues after treatment, relative to the net revenue received with no investment in control. Economic returns for the impact of reduced poisoning were calculated separately from the effects of an increase in the potential stocking rate. Total revenues were based on the averages of the most recent 10 years of Amarillo Auction Sales prices for steers, heifers, and cull cows. Price risk was modeled by considering a low price as 1 standard deviation below the mean and a high price level as 1 standard deviation above the mean. The prices used in the analysis are shown in Table 2. Total revenue per CPU was found by factoring in each of the estimated production parameters to determine the fractional number of head and sale weights produced by a CPU and multiplying by the respective cattle price.

Net revenues for each combination of annual herbage yield were calculated by subtracting the production costs from total revenue. Costs were adapted from Texas Agricultural Extension Service (1988) budgets. No land or management costs were specified. Additional variable costs associated with increasing the stocking rate were applied to the CPUs purchased to take advantage of additional forage. Additional expenses include feed, interest, labor, marketing, and miscellaneous calf costs.

The sum of the annual net revenues from the 2 treatment effects on beef production were discounted using rates 3,7 , and $11 \%$ to model the effects of interest rate variability on the net present value of the investment. The treatment was considered economically feasible if the sum of the discounted annual benefits was at least equal to the initial investment of $\$ 22.24 /$ ha, the average cost of an aerial application of liquid picloram at the herbicide label specification rate of $.28 \mathrm{~kg} / \mathrm{ha}$.

\section{Results}

The empirical response models for additional snakeweed $\left(\mathrm{AXS}_{\mathrm{t}}\right)$ and grass $\left(G_{t}\right)$ production are shown below. Numbers in parentheses under each coefficient are the significance levels for the estimated regression parameters.

$$
\begin{aligned}
\mathrm{AXS}_{\mathrm{t}}= & -1376.01-390.36 \mathrm{TR}+56.96 \mathrm{WR}-74.85 \mathrm{WR} * \mathrm{FM} \\
& (.0001)(.0856)(.000) \quad(.0001) \\
& +17.49 \mathrm{SR}^{*} \mathrm{FM}-3248.37 \mathrm{ST}_{2}-2263.99 \mathrm{ST}_{3} \\
& (.0011) \quad(.0001) \quad(.0001) \\
& -1410.43 \mathrm{ST}_{4}-882.62 \mathrm{ST}_{5}+65.31 \mathrm{t}^{2} \\
& (.0001) \quad(.0423)(.0416)
\end{aligned}
$$

Adjusted $R^{2}=.74$

$F=20.70$

\begin{tabular}{|c|c|c|c|c|c|c|c|c|c|c|c|}
\hline \multirow[b]{2}{*}{$\begin{array}{l}\text { Post } \\
\text { Tmt. } \\
\text { year }\end{array}$} & \multicolumn{2}{|c|}{ Herbage yield } & \multicolumn{3}{|c|}{ Toxicity' magnitude } & \multicolumn{4}{|c|}{ Cow herd performance } & \multicolumn{2}{|c|}{ Carrying capacity } \\
\hline & $\underset{\text { Xasa }}{\text { Xa/ha }}$ & $\begin{array}{l}\text { Grass } \\
\mathrm{kg} / \mathrm{ha}\end{array}$ & $\begin{array}{c}\text { Abort } \\
\text { rate } \\
\%\end{array}$ & $\begin{array}{c}\text { Concep } \\
\text { rate } \\
\% \text { chg }\end{array}$ & $\begin{array}{c}\text { Wean } \\
\text { wt } \\
\% \text { chg }\end{array}$ & $\begin{array}{c}\text { Calf } \\
\text { crop } \\
\%\end{array}$ & $\begin{array}{c}\text { Heifer } \\
\text { wn wt } \\
\text { kg }\end{array}$ & $\begin{array}{c}\text { Steer } \\
\mathbf{w n} w \mathrm{wt} \\
\mathbf{k g}\end{array}$ & $\begin{array}{c}\text { Cow } \\
\text { death } \\
\%\end{array}$ & $\begin{array}{l}\mathrm{Ha} \\
\text { per } \\
\mathrm{CPU}\end{array}$ & $\begin{array}{c}\text { CPU } \\
\text { per } \\
\text { ha }\end{array}$ \\
\hline & & & $\cdots$ & $\cdots$ & $\cdots-1$ & Infesta & - & & 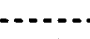 & $\cdots-\cdot$ & $\cdots$ \\
\hline * & 358 & 1139 & 0 & 0 & 0 & 85 & 193 & 204 & 1 & 8.0 & 0.1250 \\
\hline 1 & 0 & 1252 & $\mathbf{0}$ & 0 & 0 & 85 & 193 & 204 & $i$ & 7.2 & 0.1389 \\
\hline 2 & 0 & 1252 & $\mathbf{0}$ & 0 & 0 & 85 & 193 & 204 & 1 & 7.2 & 0.1389 \\
\hline 3 & 0 & 1252 & $\mathbf{0}$ & 0 & 0 & 85 & 193 & 204 & 1 & 7.2 & 0.1389 \\
\hline 4 & 0 & 1252 & $\mathbf{0}$ & 0 & 0 & 85 & 193 & 204 & 1 & 7.2 & 0.1389 \\
\hline 5 & 273 & 1166 & $\mathbf{0}$ & 0 & 0 & 85 & 193 & 204 & 1 & 7.8 & 0.1282 \\
\hline$\cdots$ & & & 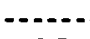 & 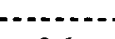 & $\cdots \cdot \mathrm{M}$ & te Infe & on -...- & $\cdots$ & -- & 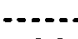 & atas \\
\hline * & 896 & 969 & 9.7 & 3.6 & 11.1 & 72 & 171 & 181 & 1 & 9.3 & 0.1075 \\
\hline 1 & $\mathbf{0}$ & 1252 & 0 & $\mathbf{0}$ & 0 & 85 & 193 & 204 & 1 & 7.2 & 0.1389 \\
\hline 2 & $\mathbf{0}$ & 1252 & 0 & $\mathbf{0}$ & 0 & 85 & 193 & 204 & 1 & 7.2 & 0.1389 \\
\hline 3 & $\mathbf{0}$ & 1252 & 0 & $\mathbf{0}$ & 0 & 85 & 193 & 204 & 1 & 7.2 & 0.1389 \\
\hline 4 & 224 & 1180 & 0 & 0 & 0 & 85 & 193 & 204 & 1 & 7.7 & 0.1299 \\
\hline 5 & 811 & 977 & 9 & 3 & 9.5 & 73 & 175 & 185 & 1 & 9.1 & 0.1099 \\
\hline$\cdots$ & & & & & 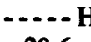 & Infest & & & & 政 & 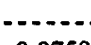 \\
\hline * & 1792 & 687 & 16.6 & 9.3 & 20.6 & 59 & 153 & 162 & 4.7 & 13.2 & 0.0758 \\
\hline 1 & 140 & 1207 & 0 & 0 & 0 & 85 & 193 & 204 & 1 & 7.5 & 0.1333 \\
\hline 2 & 336 & 1146 & 0 & 0 & 0 & 85 & 193 & 204 & 1 & 7.9 & 0.1266 \\
\hline 3 & 662 & 1043 & 6.5 & 2 & 7 & 77 & 179 & 190 & 1 & 8.7 & 0.1449 \\
\hline 4 & 1120 & 898 & 12 & 5 & 14 & 68 & 166 & 176 & 2 & 10.1 & 0.0990 \\
\hline 5 & 1707 & 713 & 16 & 8.5 & 20 & 61 & 154 & 163 & 4 & 12.7 & 0.0319 \\
\hline
\end{tabular}

$$
\begin{aligned}
& \mathrm{GR}_{\mathrm{t}}=847.60-.316 \mathrm{XS}_{\mathrm{t}}+41.30 \mathrm{SR}^{*} \mathrm{ST}_{2}+16.42 \mathrm{SR} * \mathrm{ST}_{3}
\end{aligned}
$$

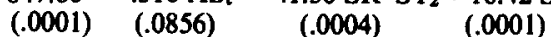

$$
\begin{aligned}
& +19.72 \mathrm{SR}^{* \mathrm{ST}_{4}}+12.26 \mathrm{SR}^{*} \mathrm{ST}_{5} \\
& \text { (.0001) } \\
& \text { Adjusted } R^{2}=.69 \\
& F+64.42
\end{aligned}
$$

The effect of winter rainfall on grass production was not statisti-

Table 4. Annual production parameters on Arvana soil after liquid picloram treatment.

-Denotes time period prior to treatment.

IOf broom snakeweed. 
Table 5. Annual costs and returns of liquid picloram treatment on Arvana soil, moderate beef prices and $7 \%$ discount rate.

\begin{tabular}{|c|c|c|c|c|c|c|c|c|c|c|c|}
\hline \multirow{3}{*}{ Year } & \multicolumn{5}{|c|}{ Results of toxicity reduction on existing CPUs } & \multicolumn{4}{|c|}{ Results of forage increase with additional CPUs } & \multicolumn{2}{|c|}{ Combined results } \\
\hline & $\begin{array}{c}\text { Total } \\
\text { Revenue }\end{array}$ & Costs & $\begin{array}{c}\text { Net } \\
\text { Return }\end{array}$ & $\begin{array}{c}\text { Added } \\
\text { Net } \\
\text { Return }\end{array}$ & $\begin{array}{c}\text { Added } \\
\text { Net } \\
\text { Return }\end{array}$ & $\begin{array}{l}\text { Added } \\
\text { CPU }\end{array}$ & $\begin{array}{l}\text { Added } \\
\text { Return }\end{array}$ & $\begin{array}{c}\text { Added } \\
\text { Variable } \\
\text { Costs }\end{array}$ & $\begin{array}{l}\text { Added } \\
\text { Net } \\
\text { Return }\end{array}$ & $\begin{array}{c}\text { Added } \\
\text { Net } \\
\text { Return }\end{array}$ & $\begin{array}{c}\text { PV } \\
\text { Added } \\
\text { NR }\end{array}$ \\
\hline & $-\cdots-\cdot-$ & $\cdots-\cdots p$ & CPU.- & ---- & $\cdots$ & 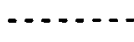 & $-\ldots$. & - - per ha & $-\cdots-1$ & 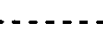 & $\cdots$ \\
\hline \multirow{8}{*}{$\begin{array}{c} \\
1 \\
2 \\
3 \\
4 \\
5 \\
\text { Sum }\end{array}$} & & & & & - & ght Infesta & - & 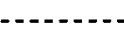 & & & -1 \\
\hline & 277.73 & 251.98 & 25.75 & 0.00 & 0.00 & 0.0000 & 0.00 & 0.00 & 0.00 & 0.00 & 0.00 \\
\hline & 277.73 & 251.98 & 25.75 & 0.00 & 0.00 & 0.0123 & 3.43 & 2.55 & 0.88 & 0.88 & 0.82 \\
\hline & 277.73 & 251.98 & 25.75 & 0.00 & 0.00 & 0.0123 & 3.43 & 2.55 & 0.88 & 0.88 & 0.77 \\
\hline & 277.73 & 251.98 & 25.75 & 0.00 & 0.00 & 0.0123 & 3.43 & 2.55 & 0.88 & 0.88 & 0.72 \\
\hline & 277.73 & 251.98 & 25.75 & 0.00 & 0.00 & 0.0123 & 3.43 & 2.55 & 0.88 & 0.88 & 0.67 \\
\hline & 277.73 & 251.98 & 25.75 & 0.00 & 0.00 & 0.0030 & 0.82 & 0.61 & 0.21 & 0.21 & 0.15 \\
\hline & & & & & 0.00 & & & & 3.72 & 3.72 & 3.12 \\
\hline \multirow{7}{*}{$\begin{array}{c}* \\
1 \\
2 \\
3 \\
4 \\
5 \\
\text { Sum }\end{array}$} & 214.67 & 251.33 & -36.66 & 0.00 & 0.00 & 0.0000 & 0.00 & 0.00 & 0.00 & 0.00 & 0.00 \\
\hline & 277.73 & 251.98 & 25.75 & 62.41 & 6.67 & 0.0311 & 8.64 & 6.43 & 2.21 & 8.88 & 8.31 \\
\hline & 277.73 & 251.98 & 25.75 & 62.41 & 6.67 & 0.0311 & 8.64 & 6.43 & 2.21 & 8.88 & 7.76 \\
\hline & 277.73 & 251.98 & 25.75 & 62.41 & 6.67 & 0.0311 & 8.64 & 6.43 & 2.21 & 8.88 & 7.25 \\
\hline & 277.73 & 251.98 & 25.75 & 62.41 & 6.67 & 0.0232 & 6.45 & 4.80 & 1.65 & 8.32 & 6.35 \\
\hline & 221.42 & 251.38 & -29.96 & 6.70 & 0.72 & 0.0030 & 0.66 & 0.61 & 0.05 & 0.76 & 0.54 \\
\hline & & & & & 27.42 & & & & 8.32 & 35.74 & 30.20 \\
\hline \multirow{8}{*}{$\begin{array}{l}* \\
0 \\
1 \\
2 \\
3 \\
4 \\
5 \\
\text { Sum }\end{array}$} & & & & & & con & & & & & \\
\hline & 149.53 & 250.68 & -101.15 & 0.00 & 0.00 & 0.0000 & 0.00 & 0.00 & 0.00 & 0.00 & 0.00 \\
\hline & 277.73 & 251.98 & 25.75 & 126.90 & 9.62 & 0.0573 & 15.92 & 11.85 & 4.07 & 13.69 & 12.80 \\
\hline & 277.73 & 251.98 & 25.75 & 126.90 & 9.62 & 0.0506 & 14.06 & 10.47 & 3.59 & 13.22 & 11.54 \\
\hline & 236.55 & 251.58 & -15.03 & 86.12 & 6.53 & 0.0393 & 9.29 & 8.10 & 1.19 & 7.72 & 6.30 \\
\hline & 194.92 & 251.13 & -56.21 & 44.94 & 3.41 & 0.0232 & 0.00 & 0.00 & 0.00 & 3.41 & 2.60 \\
\hline & 156.90 & 250.78 & -93.88 & 7.27 & 0.55 & 0.0030 & 0.00 & 0.00 & 0.00 & 0.55 & 0.39 \\
\hline & & & & & 29.73 & & & & 8.45 & 38.59 & 33.63 \\
\hline
\end{tabular}

* Denotes time period prior to treatment.

cally significant on any of the soils. As equation 2 shows, there was no statistically significant direct effect of summer rainfall on grass production with the Potter and Kimbrough-Lea soils, but an additional centimeter of summer rainfall on the other 4 soils increased grass production by 12.26 to $41.30 \mathrm{~kg} / \mathrm{ha}$. Summer rainfall also affected grass production indirectly through its effect on snakeweed (equation 1). Although pelleted (10\% ai) picloram is no longer available, the model shows that the snakeweed population is reduced more by pellets than with liquid formulation, provided adequate precipitation is received after application.

The model predicts that the rate of reinvasion is the same for all soil types. Since treatment life is terminated when $\mathrm{AXS}_{\mathrm{t}}$ becomes 0 and $\mathrm{AXS}_{\mathrm{t}}$ is a function of pre-treatment snakeweed quantity, the length of treatment life will increase with the productivity of the soil. The regression parameter of -.316 indicates that $1 \mathrm{~kg}$ of grass is replaced by $3 \mathbf{~ k g s}$ of snakeweed on all soil types in the data set.

The results of using the single variable GR equations to establish pre-treatment levels of forage are shown in Table 3 . The grass and snakeweed yields by level of snakeweed infestation in Table 3 have the effects of rainfall and treatment rate variations removed. The difference in grass yield between infestation levels is $.316^{*}$ the snakeweed yield for the higher infestation level. The KimbroughLea and Potter soils were omitted from the economic analysis because in the data set used an abnormally low snakeweed kill rate occurred on those soils without apparent reason, and the response for those soils was judged to be unreliable. Table 4 shows the predicted herbage yields through time for the Arvana soil. Also shown are toxicity parameters, and the resultant cow herd performance values associated with the snakeweed quantity in a given year.

Table 5 shows costs and returns based on the biological information supplied in Table 4. In this example, treatment of the moderate and heavy infestation levels was determined to be economically feasible with moderate beef prices and a discount rate of $7 \%$. For the heavy infestation, the summation of the annual net revenues is expected to result in a value of $\$ 33.63 /$ ha (last column), thus exceeding treatment costs by $\$ 11.39 / \mathrm{ha}$. Similar tables were developed for the 3 levels of infestation on each soil and under different beef price levels and discount rates. The results of the modeled treatments are shown in Table 6 and support several economic implications.

With $\$ 22.24 /$ ha treatment costs, it does not pay to treat a light infestation on any of the soil types, even with high beef prices and low discount rates. However, even with low beef prices and a high discount rate, treatments on the $\mathbf{4}$ soils are generally economically feasible if at least a moderate infestation is present before control. Returns are reduced for all treatments by an increase in the discount rate and/or decrease in beef prices, but the impacts change economic feasibility only with a moderate infestation on the Arvana soil, the poorest soil of the 4. Economic returns are greater on the more productive soils.

The results also indicate that the economic benefits from reducing the extent of poisoning and improving CPU output exceed the benefits obtained from increasing forage yields with commensurate increases in stocking rate (Table 7). Reducing toxicity accounts for approximately $77 \%$ of the benefits averaged across all soils with a moderate or heavy infestation. Of the 8 treatments which were economically feasible with moderate beef prices and a $7 \%$ discount rate, all of them pay solely because of reduced poisoning, while only 1 of the treatment situations in the analysis (Miles soil, heavy infestation) is economically feasible on the basis of the forage response alone.

The economic impact of poisoning is also apparent in years 4 and 5 of the example in Table 5. As snakeweed reinvades the site, economic losses from poisoning cancel any benefits that would be received from increasing the stocking rate. Although additional forage is available, it costs more to carry the additional CPUs than the value of their output. The enterprise is not making positive 
Table 6. Effects of beef price levels and discount rate on economlc returns.

\begin{tabular}{|c|c|c|c|c|c|c|c|c|c|}
\hline \multirow[b]{2}{*}{$\begin{array}{l}\text { Infest. } \\
\text { Level }\end{array}$} & \multicolumn{3}{|c|}{ Low prices } & \multicolumn{3}{|c|}{ Average prices } & \multicolumn{3}{|c|}{ High prices } \\
\hline & 3 & 7 & 11 & 3 & $\begin{array}{c}\text { count } \\
7\end{array}$ & 11 & 3 & $\frac{7}{7}$ & 11 \\
\hline $\begin{array}{l}\text { Light } \\
\text { Moderate } \\
\text { Heavy }\end{array}$ & $\begin{array}{r}1.57 \\
25.17 \\
27.28\end{array}$ & $\begin{array}{r}1.42 \\
22.90 \\
25.23\end{array}$ & $\begin{array}{r}1.29 \\
20.95 \\
23.44\end{array}$ & $\begin{array}{r}3.44 \\
33.19 \\
36.32\end{array}$ & $\begin{array}{r}3.12 \\
30.20 \\
33.63\end{array}$ & $\begin{array}{r}2.84 \\
27.65 \\
31.28\end{array}$ & $\begin{array}{r}5.32 \\
41.25 \\
45.46\end{array}$ & $\begin{array}{r}4.82 \\
37.55 \\
42.12\end{array}$ & $\begin{array}{r}4.40 \\
34.37 \\
39.20\end{array}$ \\
\hline $\begin{array}{l}\text { Light } \\
\text { Moderate } \\
\text { Heavy }\end{array}$ & $\begin{array}{r}1.97 \\
35.31 \\
55.31\end{array}$ & $\begin{array}{r}1.77 \\
31.60 \\
49.65\end{array}$ & $\begin{array}{r}1.59 \\
28.49 \\
44.87\end{array}$ & $\begin{array}{r}4.34 \\
44.69 \\
72.30\end{array}$ & $\begin{array}{r}\text { Soil - } \\
3.88 \\
39.99 \\
64.91\end{array}$ & $\begin{array}{r}3.50 \\
36.05 \\
58.68\end{array}$ & $\begin{array}{r}6.70 \\
54.06 \\
89.28\end{array}$ & $\begin{array}{r}6.00 \\
48.38 \\
80.17\end{array}$ & $\begin{array}{r}5.41 \\
43.62 \\
72.49\end{array}$ \\
\hline $\begin{array}{l}\text { Light } \\
\text { Moderate } \\
\text { Heavy }\end{array}$ & $\begin{array}{r}2.08 \\
65.80 \\
62.50\end{array}$ & $\begin{array}{r}1.86 \\
59.18 \\
58.78\end{array}$ & $\begin{array}{r}1.68 \\
53.63 \\
55.53\end{array}$ & $\begin{array}{r}4.58 \\
86.04 \\
73.48\end{array}$ & $\begin{array}{r}4.10 \\
77.40 \\
68.88\end{array}$ & $\begin{array}{r}3.69 \\
70.16 \\
64.86\end{array}$ & $\begin{array}{r}7.07 \\
106.28 \\
91.51\end{array}$ & $\begin{array}{r}6.33 \\
95.62 \\
85.81\end{array}$ & $\begin{array}{r}5.71 \\
86.69 \\
80.81\end{array}$ \\
\hline $\begin{array}{l}\text { Light } \\
\text { Moderate } \\
\text { Heavy }\end{array}$ & $\begin{array}{r}3.47 \\
53.76 \\
76.28\end{array}$ & $\begin{array}{r}3.11 \\
48.11 \\
68.55\end{array}$ & $\begin{array}{r}2.80 \\
43.37 \\
62.03\end{array}$ & $\begin{array}{r}7.63 \\
72.00 \\
105.62\end{array}$ & $\begin{array}{r}6.83 \\
64.44 \\
94.92\end{array}$ & $\begin{array}{r}6.16 \\
58.09 \\
85.91\end{array}$ & $\begin{array}{r}11.79 \\
90.24 \\
134.98\end{array}$ & $\begin{array}{r}10.55 \\
80.76 \\
121.32\end{array}$ & $\begin{array}{r}9.51 \\
72.80 \\
109.81\end{array}$ \\
\hline
\end{tabular}

Table 7. Effects of snakeweed poisoning reduction and increased forage production with average beef prices and $7 \%$ discount rate (S/ha).

\begin{tabular}{|c|c|c|c|c|c|}
\hline $\begin{array}{l}\text { Infestation } \\
\text { level }\end{array}$ & $\begin{array}{c}\text { Trmt. } \\
\text { life }\end{array}$ & $\begin{array}{l}\text { Poisoning } \\
\text { reduction }\end{array}$ & $\begin{array}{c}\text { Increased } \\
\text { forage }\end{array}$ & $\begin{array}{c}\text { Total } \\
\text { effects }\end{array}$ & $\begin{array}{l}\% \text { due to } \\
\text { poisoning } \\
\text { reduction }\end{array}$ \\
\hline \multicolumn{6}{|c|}{ (1) } \\
\hline Light & 5 & 0.00 & 3.12 & 3.12 & $\mathbf{0}$ \\
\hline Moderate & 5 & & & & 77 \\
\hline Heavy & 5 & 25.72 & 7.91 & 39.09 & 76 \\
\hline \multicolumn{6}{|c|}{ - Vernon Soil -2} \\
\hline Light & 6 & 0.00 & 3.88 & 3.88 & 0 \\
\hline Moderate & 6 & 33.81 & 6.18 & 39.99 & 85 \\
\hline Heavy & 6 & 50.46 & 14.46 & 64.91 & 77 \\
\hline \multicolumn{6}{|c|}{ - Tina Soil $=1$} \\
\hline Light & 5 & 0.00 & 4.10 & 4.10 & 0 \\
\hline Moderate & 5 & 60.43 & 16.97 & 77.40 & 78 \\
\hline Heavy & 5 & 54.19 & 14.69 & 68.88 & 79 \\
\hline \multicolumn{6}{|c|}{ - } \\
\hline Light & 7 & 0.00 & 6.83 & 6.83 & 0 \\
\hline Moderate & 7 & 47.70 & 17.03 & 64.44 & 74 \\
\hline Heavy & 7 & 64.21 & 30.71 & 94.92 & 68 \\
\hline
\end{tabular}

returns in years $3-5$, but the treatment is still generating economic benefits because the dollar losses in these years are less than they were prior to treatment.

\section{Conclusions}

Based on the results of this study, the use of picloram is an economically sound option for controlling moderate to heavy infestations of broom snakeweed in the southern plains. Treatment of light infestations under normal environmental or economic conditions is not advisable. This general conclusion holds for all levels of cattle prices and discount rates analyzed in this study. This analysis also shows that benefits from controlling snakeweed accrue from both additional grass production and increased livestock production efficiency, but the livestock efficiency gains add more to revenues than does the added grass production when snakeweed is controlled.

There is a degree of uncertainty associated with any control since the response occurs in the future. Many variables which influence profitability, e.g., precipitation, cattle prices, discount rates, pro- duction costs and the productive capacity of the site, cannot be controlled by the rancher or may be managed to only a limited degree. Additionally, the economic benefits are only those which accrue through the market place. Individual investment decisions may be influenced by financial considerations which effectively lower the cost to an individual. For example, cost-share programs may make it economically feasible for individual producers to treat areas that would otherwise be unprofitable. Also, the estimated benefits in this study are pre-tax values, which may have ramifications for some individuals. For individual rancher investment decisions, the proper use of this study is the adaptation of the procedures and implications.

\section{Literature Cited}

Alliney, J.E. 1982. Carbohydrate trends in broom snakeweed (Xanthocethalum sarothrae). M.S. thesis, Texas Tech Univ., Lubbock.

Carpenter, B.D., D.E. Ethridge, and R.E. Sosebee. 1991. Economic losses from broom snakeweed poisoning in cattle. Rangelands 15:175-185.

Courtney, R.W. 1984. Influence of site characteristics and phenology on carbohydrate trends in broom snakeweed (Xanthocethalum sarothrae). M.S. thesis, Texas Tech Univ., Lubbock.

Dollahite, J.W., and J.T. Allen. 1959. Feeding perennial broomweed to cattle, swine, sheep, goats, rabbits, guinea pigs and chickens. Tex. Agr. Exp. Sta. PR-2105.

Dollahite, J.W., and W.V. Anthony. 1956. Experimental production of abortion, premature calves and retained placentas by feeding a species of perennial broomweed. Tex. Agr. Exp. Sta. PR-1884.

Dollahite, J.W., and W.V. Anthony. 1957. Poisoning of cattle with Gutierrezia microcephala, a perennial broomweed. Amer. Vet. Med. Assoc. J. 13:525.

Ethridge, D.E., B.E. Dahl, and R.E. Sosebee. 1984. Economic evaluation of chemical mesquite control using 2,4,5-T. J. Range Manage. 37:152-156.

Ethridge, D.E., R.D. Pettit, T.J. Neal, and V.E. Jones. 1987. Economic returns from treating sand shinnery oak with tebuthiuron in west Texas. J. Range Manage. 40:346-348.

Ethridge, D.E., R.G. Sudderth, and H.A. Wright. 1985. Economic returns from burning tobosagrass in the Texas rolling plains. J. Range Manage. 38:362-365.

Gesink, R.W., H.P. Alley, and G.A. Lee. 1973. Vegetative response to chemical control of broom snakeweed on a blue grama range. J. Range Manage. 26:139-143.

MeDaniel, K.C., and R.W. Duncan. 1987. Broom snakeweed control with picloram and metsulfuron. Weed Sci. 35:837-841.

McDaniel, K.C., and R.E. Sosebee. 1987. Taxonomy, ecology, and poisonous properties associated with perennial snakeweeds. In: L.F. James, M.H. Ralphs, and D.B. Nielson (eds). The Ecology and Economic Impact of Poisonous Plants on Livestock Production. Westview Press, Boulder, Colo. 
McDaniel, K.C., R.D. Pieper, and G.B. Donart. 1982. Grass response following thinning of broom snakeweed. J. Range Manage. 35:219-222.

Sosebee, R.E. 1985. Timing- the key to herbicidal control of broom snakeweed. Tex. Tech Univ. Dept. of Range and Wildl. Mange. Manage. Note No. 6.

Sosebee, R.E., D.J. Bednnah, W. Siepp, G.L. Thompson, and R. Henard. 1981. Herbicidal control of broom snakeweed. Down to Earth. 37:17-24. Sosebee, R.E., W.E. Boyd, and C.S. Brumley. 1979. Broom snakeweed control with tebuthiuron. J. Range Manage. 32:179-182.
Texas Agricultural Extension Service. 1988. Texas enterprise budgetsSouth Plains district. College Station, Texas.

Torell, A.L., H.W. Gordon, K.C. McDaniel, and A. McGinty. 1987. Economic impacts of perennial snakeweed infestations. In: L.F. James, M.H. Ralphs, and D.B. Nielsen (eds.). The Ecology and Economic Impact of Poisonous Plants on Livestock Production. Westview Press, Boulder, Colo.

U.S. Dept. of Commerce. 1979-1987. Climatological data; Texas and New Mexico. Environ. Sci. Publ. weekly.

Ueckert, D.N. 1979. Broom snakeweed: effect on shortgrass forage production and soil water depletion. J. Range Manage. 32:216-220. 